\title{
Effects of waste PVC addition on the properties of (40-50) grade asphalt
}

\author{
Nawal Salman ${ }^{1, *}$ and Zeena Jaleel ${ }^{1}$ \\ ${ }^{1}$ Building and Construction Engineering Department, University of Technology, Baghdad, Iraq
}

\begin{abstract}
Disposal of plastic waste poses a serious threat nowadays. Effective solutions are required to reduce or eliminate this problem. One of these solutions is to use these materials in asphalt mixtures. PVC (Poly Vinyl Chloride) during melting has adhesive properties which can be used with asphalt to reduce the bitumen mixture costs. Investigation of physical characteristics of asphalt cement (40-50) mixed with PVC is presented in this paper. The main objective is to study the change in bitumen properties after mixing with PVC of percent $(2.5,5,7.5,10,12$ and 15$) \%$ by weight of bitumen. Penetration, ductility, loss on heating, softening point, flash and fire tests were conducted for each percent. It is concluded that penetration decreases by $62.8 \%$ on addition of $15 \%$ PVC. Ductility also drops when PVC dosage increases. Softening point increases when PVC dosage increases by $6 \%$ for $15 \%$ PVC.
\end{abstract}

\section{Introduction}

There is an urgent requirement to improve the road performance in view of the increase in traffic volume on roads and overloading of transport vehicles along with an absence of effective legislation to protect the highways, and also due to the significant difference in temperatures during day and night and across seasons. Hence the need to improve the properties of asphalt material. Population increase and industrial growth throughout the world result in creation and production of new types of non-biodegradable plastic waste. Recent studies have shown that plastic waste can stay on earth for 4500 years unchanged and without degradation. [1] In order to reduce pollution due to plastic waste an effective solution for recycling must be found. One such solution is the use of plastic waste materials in flexible pavement mixture. This process can reduce the cost of construction. The use of plastic wastes with asphalt mixture in pavement construction is not a new work. The idea began to spread across the world in the last two decades, where researchers have put together various ideas and researches to find alternatives to the use of plastic waste with asphalt.

Rajasekaran et al. [2] investigated possibility of Polyethylene polypropylene polystyrene in coating aggregate, which is showing better aggregate properties that can be used in flexible pavement construction. Marshall Mix sample prepared using the coated aggregate. Marshall Stability improve in range of (1820) $\mathrm{kN}$. This process is environment friendly and helps reduce costs.

Rahman et al. [3] used two types of plastic waste, polyethylene and PVC to improve asphalt mixture properties using Marshall Mix design. The tests includes measurement of unit weight, stability, flow, and V.T.M, the study concluded that polyethylene modifier up to 10 $\%$ and PVC up to $7.5 \%$, can be used for flexible pavement construction".

Chavan [4] utilized waste plastic bags in coating the aggregate then used in the asphalt mixture to enhance properties of asphalt mix besides solving the plastic waste problems"

Gawandea etal. [5] Reviewed developed techniques to use plastic wastes for construction of flexible pavement. Bitumen material can be modified by using plastic waste, so the modified mixture can be used on the wearing surface of the pavement. The modified mixtures show good stability, flow and moisture resistance.

Jassim et al. [6], investigated stability of Marshall and retained strength index to evaluate plastic waste particles properties such as thickness, size and content percent. Basis results of the tests, it was found that the plastic waste reduced to a thin size of fine particles, thin thickness resulted in developing stability of Marshall and water resistance to damage, and could also solve environmental problems.

\section{Materials}

\subsection{Asphalt material}

The asphalt material used for this study is (40-50) penetration graded bitumen, which is supplied by AlDura refinery in Baghdad city. Al-Dura refinery produces asphalt cement graded from refined crude oil petroleum, which is used for pavement construction. Usually the penetration graded asphalt classified to (40-

\footnotetext{
* Corresponding author: $\underline{40096 @ \text {,uotechnology.edu.iq }}$
} 
50), (50-60), (60-70), (85-100), (120-150), (200-300). Standard ASTM tests were performed on the original bitumen getting the following properties shown in Table 1 .

Table 1. Test Results for the Origin Bitumen Material

\begin{tabular}{|l|l|l|l|l|}
\hline Property & $\begin{array}{l}\text { Unit } \\
\text { s }\end{array}$ & $\begin{array}{l}\text { ASTM } \\
\text { Designation }\end{array}$ & $\begin{array}{l}\text { Test } \\
\text { Results }\end{array}$ & $\begin{array}{l}\text { SCRB } \\
\text { Specification }\end{array}$ \\
\hline $\begin{array}{l}\text { Penetration } \\
\text { at } 25^{0} \mathrm{C} \\
, 100 \mathrm{gm}, 5 \\
\text { sec. }\end{array}$ & $\begin{array}{l}0.1 \\
\mathrm{~mm}\end{array}$ & $\mathrm{D}-5-86$ & 43 & $40-50$ \\
\hline Flash point & ${ }^{0} \mathrm{C}$ & $\mathrm{D}-92$ & 342 & Min.232 \\
\hline Fire point & ${ }^{0} \mathrm{C}$ & $\mathrm{D}-92$ & 345 & - \\
\hline $\begin{array}{l}\text { Softening } \\
\text { point }\end{array}$ & ${ }^{0} \mathrm{C}$ & $\mathrm{D}-36-86$ & 52.5 & $(51-62)$ \\
\hline $\begin{array}{l}\text { Ductility at } \\
25{ }^{0} \mathrm{C}, 5 \\
\text { cm } / \text { min. }\end{array}$ & $\mathrm{cm}$ & $\mathrm{D}-113-79$ & 105 & $>100$ \\
\hline $\begin{array}{l}\text { Loss on } \\
\text { heating }(\% \\
\text { max.) }\end{array}$ & $\%$ & $\mathrm{D}-1754-83$ & 0.3 & $0.75 \%$ \\
\hline
\end{tabular}

\subsection{Poly Vinyl Chloride (PVC)}

Plastic waste may be grouped depending on their physical properties to thermoplastic and thermosetting materials. Thermoplastic materials can be formed into any desired shape under the effect of pressure and heat. Thermoplastic materials become solid when cooled. Some examples of thermoplastic and thermosetting materials are tabulated below in Table 2. [1]. Plastics can also be classified according to their chemical sources. According to sources of plastic, there are six types: Cellulose Plastics, Synthetic Resin Plastics, Protein Plastics, Natural Resins, Elastomers and Fibres. Table 3 gives the source of waste plastic generation. [1]. The essential raw materials for PVC are derived from salt and oil. PVC is manufactured from two starting materials;

- $57 \%$ of the molecular weight derived from common salt

- $43 \%$ derived from hyrdocarbon feedstocks (increasingly ethylene from sugar crops is also being used for PVC production as an alternative to ethylene from oil or natural gas). [7]

Table 2. Typical Thermoplastic and Thermosetting Resins [1]

\begin{tabular}{|l|l|}
\hline \multicolumn{1}{|c|}{ Thermoplastic } & \multicolumn{2}{c|}{ Thermosetting } \\
\hline Polyethylene Teryphthalate(PET) & Bakelite \\
\hline Polypropylene (PP) & Epoxy \\
\hline Poly Vinyl Acetate (PVA) & Melamine \\
\hline Poly Vinyl Chloride(PVC) & Polyester \\
\hline Polystyrene (PS) & Urea - Formaldehyde \\
\hline Low Density Polyethylene (LDPE) & Alkyd \\
\hline High Density Polyethylene (HDPE) & \\
\hline
\end{tabular}

Table 3. Waste Plastic \& its Source [1]

\begin{tabular}{|c|c|}
\hline Waste Faste & Origa \\
\hline 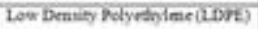 & 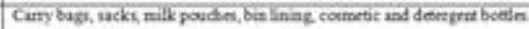 \\
\hline Miphensiny Adyedolense (HDPE) & Camy bags, berde cass, boest hald andes the. \\
\hline 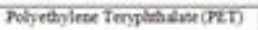 & Drakiag wower bethes et: \\
\hline pospropstere (m) & 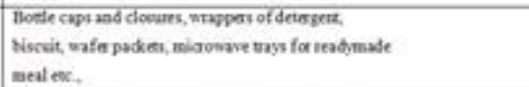 \\
\hline Powhentere (क) & 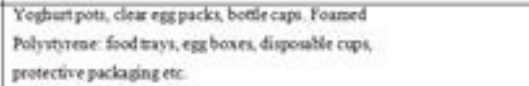 \\
\hline Pobvaylctoride (P)C) & 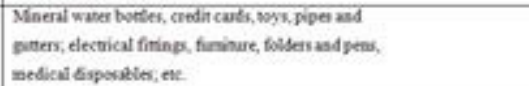 \\
\hline
\end{tabular}

$\mathrm{PVC}$ is a polymer having only aliphatic (linear) carbon atoms in their backbone chains. [8]. Table (4) shows some of physical properties for PVC. [8]

Table 4. Physical Properties for PVC

\begin{tabular}{|c|c|c|c|c|}
\hline $\begin{array}{c}\text { Density } \\
\mathrm{gm} / \mathrm{cm}^{3}\end{array}$ & $\begin{array}{c}\text { Tensile } \\
\text { strength } \\
\mathrm{MPa}\end{array}$ & $\begin{array}{c}\text { Elongation } \\
\text { at break \% }\end{array}$ & $\begin{array}{c}\text { Flexural } \\
\text { Modulus } \\
\mathrm{GPa}\end{array}$ & $\begin{array}{c}\text { Thermal } \\
\text { coefficient } \\
\text { expansion }\end{array}$ \\
\hline $1.3-1.6$ & $40-50$ & $2-80$ & $2.1-3.4$ & $80 * 10^{-6}$ \\
\hline
\end{tabular}

PVC is chemically resistant to acids, salts, bases, fats, and alcohols. It is also resistant to some solvents for example, PVC is resistant to fuel and some paint thinners. Some solvents may only swell it or deform it but not dissolve it, but some of them like tetrahydrofuran or acetone, may damage it. [8]

\section{Plastic PVC preparation}

PVC collected from factories which produce PVC doors and windows to house construction. The plastic waste is cleaned well to ensure no unwanted material.

\subsection{PVC Shredding}

Shredding is cutting the PVC into small particle sizes between 2.5 to $3.0 \mathrm{~mm}$ by shredding machine from the seller where the waste PVC supplied.

\subsection{Preparation of blend}

First step to mix PVC with asphalt was heating the PVC particles until they soften then added to hot asphalt. It was found that PVC particles soften at $(180-200){ }^{\circ} \mathrm{C}$. This process would fail if the PVC particles are gathered and clustered. Particles were added gradually to hot asphalt of (180-200) $\mathrm{C}^{\circ}$. PVC mixed with percent of (2.5, $5,7.5,10,12$, and 15$) \%$ by weight of bitumen until plastic waste mixture with bitumen became homogeneous. Figure (1) shows the shredded PVC. Figure (2) shows mixing process with bitumen. 

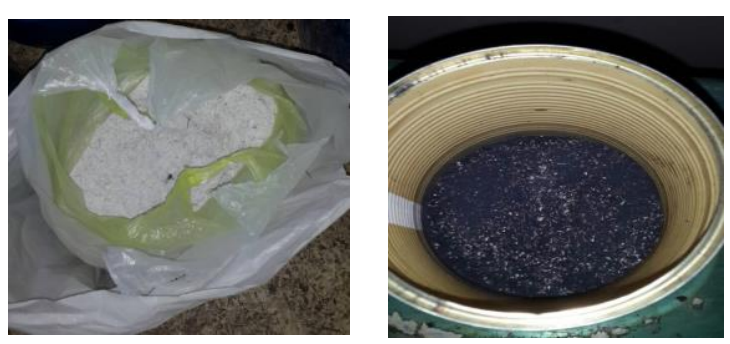

Fig. 1. Shredded PVC

Fig. 2. Mix PVC with Bitumen

\section{Experimental works}

Standard ASTM tests were conducted for the PVC and asphalt cement mixture. These tests included penetration, ductility loss on heating, softening point, flash and fire test. PVC added to (40-50) graded asphalt with percent of $(2.5,5,7.5,10,12$ and 15$)$ by weight of bitumen. Test results are shown in Table (5). Penetration Index (P.I) also calculated for each percent to detect asphalt temperature susceptibility. P.I calculated from equation 1:

$$
\frac{20-P . I}{10+P . I}=50 * \frac{\log (800)-\log (\text { penteration. })}{T_{r b}-T_{\text {penteration }}}
$$

Where:

$\mathrm{P} . \mathrm{I}=$ penetration index

$\mathrm{Trb}=$ softening point temperature

Tpenteration $=$ penetration temperature $=25^{\circ} \mathrm{C}$

P.I range from $(-2,2)$ which indicate normal temperature susceptibility. P.I greater than 2 indicates low temperature susceptibility, while P.I less than -2 indicates high temperature susceptibility. [9]

\section{Results and Discussion}

The Penetration values decrease significantly when (4050 ) bitumen is mixed with the modifier (PVC). The original grade decreases by $62.8 \%$ on adding $15 \%$ of PVC by weight of bitumen. Figure (3) shows the relationship between penetration and PVC content. It may be seen that the ductility values for bitumen modified with 12 and 15 percent are very low compared to original binders. It drops from $105 \mathrm{~cm}$ to $16 \mathrm{~cm}$ at 15 $\%$ PVC. The ductility values decrease with the increase in percentage of modifier (PVC) because asphalt becomes harder.

Table 5 Properties of Asphalt with PVC
Figure (4) shows the relation between Ductility and PVC percent. Penetration and ductility values decrease with the increase in dosage of PVC. Plastic materials are organic polymers which are usually solid so penetration

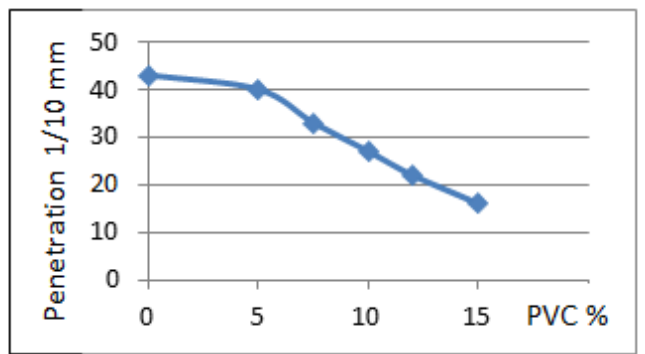

Fig. 3. Relation between Penetration and PVC

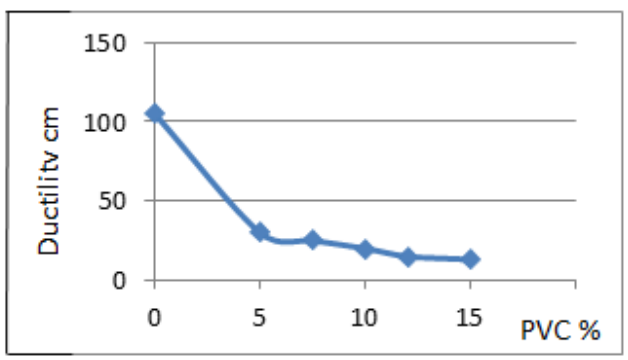

Fig. 4. Relation between Ductility and PVC

The softening point increases with the increase in percentage of PVC dosage because the bitumen becomes increasingly more brittle. Softening point of bitumen increase to $55.8{ }^{\circ} \mathrm{C}$ by the addition of $15 \%$ PVC. It's increased by $6 \%$. Figure (5) shows softening point with PVC\%. Penetration Index P.I was calculated for each percent to detect temperature susceptibility for asphalt material after adding PVC. The calculation results are illustrated in Table (5) which shows that penetration index decreases with increase in PVC \%. The penetration index from $2.5 \%$ to $12 \%$ indicate normal susceptibility to temperature, while at $15 \%$ PVC asphalt material become high susceptibility. Figure (6) shows the relation between P.I and PVC\%.

Flash and fire points decrease with PVC increase, this can be shown in Figure (7). Flash point decreases from $345^{\circ} \mathrm{C}$ to $286^{\circ} \mathrm{C}$ when adding $15 \%$ PVC, which meets the Iraqi standards that specifies minimum $232{ }^{\circ} \mathrm{C}$ as a flash point. Flash point decreases by $23 \%$, while fire point decrease by $22 \%$ on addition of $15 \%$ PVC.

\begin{tabular}{|c|c|c|c|c|c|c|c|c|}
\hline $\begin{array}{c}\text { PVC } \\
\%\end{array}$ & $\begin{array}{c}\text { Penetration } \\
(1 / 10) \mathrm{mm}\end{array}$ & $\begin{array}{c}\text { Ductility } \\
\mathrm{cm}\end{array}$ & $\begin{array}{c}\text { Softening } \\
\text { Point } \mathrm{C}^{\mathrm{o}}\end{array}$ & $\begin{array}{c}\text { Flash } \\
\text { point } \\
\mathrm{C}^{\mathrm{o}}\end{array}$ & $\begin{array}{c}\text { Fire } \\
\text { point } \mathrm{C}^{\mathrm{o}}\end{array}$ & $\begin{array}{c}\text { Loss on } \\
\text { Heating }\end{array}$ & $\begin{array}{c}\text { Penetration } \\
\text { Index }\end{array}$ & $\begin{array}{c}\text { Penetration } \\
\text { Index } \\
\text { Reflection }\end{array}$ \\
\hline 0 & 43 & 105 & 52.5 & 342 & 345 & 0.3 & -0.934 & Normal \\
\hline 2.5 & 42 & 50 & 52.7 & 340 & 343 & 0.35 & -0.937 & Normal \\
\hline 5 & 40 & 30 & 53 & 337 & 340 & 0.4 & -0.972 & Normal \\
\hline 7.5 & 33 & 25 & 54 & 320 & 325 & 0.4 & -1.14 & Normal \\
\hline 10 & 27 & 20 & 54.5 & 300 & 308 & 0.4 & -1.416 & Normal \\
\hline 12 & 22 & 15 & 55.6 & 282 & 285 & 0.6 & -1.552 & Normal \\
\hline 15 & 16 & 13 & 55.8 & 263 & 268 & 0.8 & -2.017 & High \\
\hline
\end{tabular}




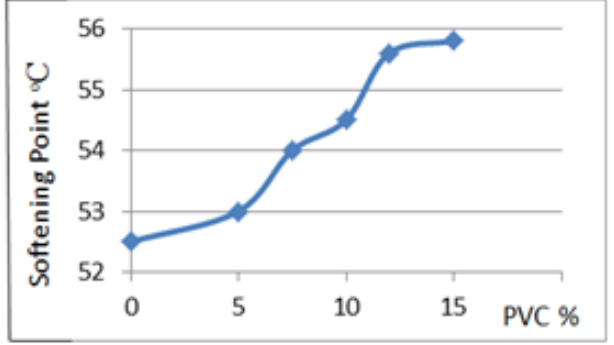

Fig. 5. Relation between Softening Point \& PVC

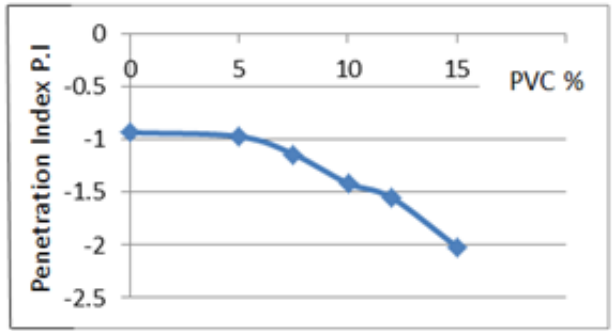

Fig. 6. Relation between P.I \& and PVC

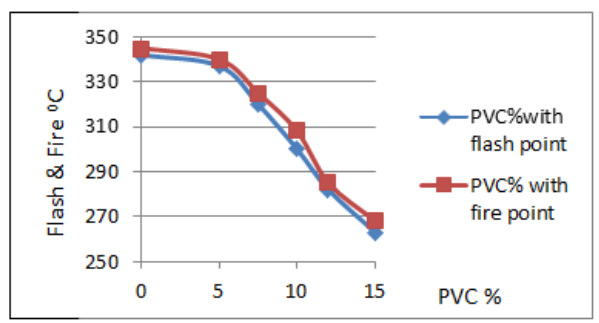

Fig.7. Relation between Flash \& Fire Point \& PVC

Loss on heating test shows convergent results, at $2.5 \%$ of PVC the loss was $0.35 \%$, at $(5,7.5,10)$ the loss value was $0.4 \%$, at $12 \%$ the loss was $0.6 \%$, all these results meet the Iraqi standards which permits maximum loss value as $0.75 \%$. The last percent of PVC \% (15) recorded $0.8 \%$ loss value, which was out of the range of specification. Figure (8) represents the loss on heating value.

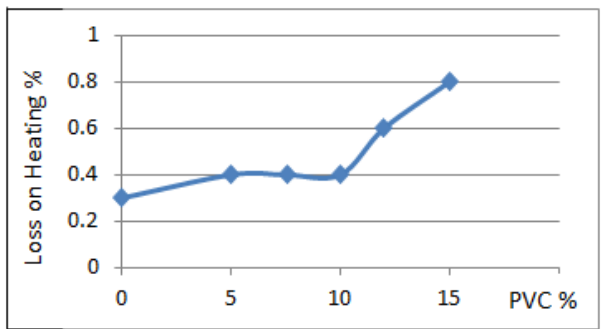

Fig. 8. PVC\% with Loss on Heating Value

\section{Conclusions}

This study investigates the use of PVC with bitumen as additives to study the change in physical properties of (40-50) graded asphalt. From the experimental work, the following can be concluded:

1. Penetration decreased by $62.8 \%$ on addition of $15 \%$ PVC. Generally asphalt became harder with the increase of PVC dosage.
2. Ductility value decreased with increase in PVC dosage. Ductility value dropped from $105 \mathrm{~cm}$ with $0 \%$ PVC to $16 \mathrm{~cm}$ on adding $15 \%$ PVC.

3. Softening point increased with the increase in PVC dosage. It increased by $6 \%$ on adding 15 $\%$ PVC.

4. Penetration Index (P.I) decreased with an increase in PVC dosage. With PVC percent of $(5,7.5,10,12) \%$ asphalt cement has normal susceptibility to temperature, while with PVC dosage of $15 \%$ the asphalt cement becomes highly susceptible to temperature.

5. Flash point decreased by $23 \%$ when PVC \% dosage increased.

6. Fire point decreased by $22 \%$ when PVC \% dosage increased.

7. Loss on heating value increased from ( 0.3 to $0.6) \%$ when PVC dosage increased. $15 \%$ PVC recorded $0.8 \%$ loss on heating value which is outside the range of the specifications.

\section{Recommendations}

Further research may be carried out on softer grade of asphalt like (85-100), (120-150) and also on other types of PVC like plastic bottles, carrying bags, pipes...... etc.

\section{References}

1. Indian Roads Congress, (2013).

2. S.Rajasekaran1, R. Vasudevan, S. Paulraj, AJER eISSN: 2320-0847 p - ISSN: 2320-0936, 2, 11, 0113, (2013).

3. Md. N. Rahman, M. Ahmeduzzaman, M. A. Sobhan, T. U. Ahmed, AJCEA, 1, 5, 97-102, (2013).

4. A. J. Chavan1, (IJAIEM), 2, 4, April (2013).

5. A. Gawandea, G. Zamarea, V.C. Rengea, S. Taydea, and G. Bharsakaleb, JERS, 3, 2, (2012).

6. H. M. Jassim , O. T. Mahmood, S. A. Ahmed, (IJETT), 7,1 , (2014).

7. http://www.bpf.co.uk/plastipedia/polymers/PVC

8. https://www.britannica.com/science/plastic

9. J. Read, D. Whiteoak, The Sell Bitumen Handbook, Sixth Edition, Shell Bitumen, UK, (2015). 